\title{
YEAR ROUND HOMESTEAD VEGETABLE PRODUCTION: A MEANS OF REDUCING POVERTY AND NUTRITIONAL DEFICIENCY FOR SMALL FARM
}

\author{
M. A. H. KHAN ${ }^{1}$, M. YUSUF ALI' ${ }^{2}$, M. A. QUAYYUM ${ }^{4}$, \\ M. I. NAZRUL ${ }^{5}$ AND M. J. HOSSAIN ${ }^{5}$
}

Key Words: Homestead, poverty and nutritional deficiency

Bangladesh has about 12 million farm households of which 9.4 millions are small (BBS, 2005). In Tangail District, small households are about 3.3 lac. In Bangladesh, per capita vegetable consumption is only $28 \mathrm{~g}$ against the daily requirement of $200 \mathrm{~g}$ (Chadha et al., 1994). Over 30 thousand infants become blind every year due to vitamin 'A' deficiency (BARC, 1 990). Vitamin C, iron, and other mineral nutritional deficiency are widespread resulting in different types of diseases, hampering physical growth and retarding brain development. This situation aggravates when any natural disaster occurs in any areas. Approximately $5 \%$ area ( 0.45 million hectares) of the total 8.4 million hectares of cultivable land is occupied by homesteads. The size of homestead varies depending on agro-ecology and farm size. There are about 18-20 million families in Bangladesh, most of them live in rural areas having a homestead for each. Their homesteads are the most effective and common production units for supplying food, fuel, timber, and other family needs and employing family labours.

Homesteads include vegetables gardening, livestock rearing, poultry raising, fish culture, homestead forestry, post-harvest processing and alike activities. The actual area of homestead devoted to vegetable cultivation is very small. Hussain et al. (1988) reported that about $13 \%$ of the total homestead area was under vegetable production. Small farmers have some crop field. Usually they are to maintain their livelihood by utilizing the homestead and crop field. However, many small homestead areas of Bangladesh remain unutilized, which could be brought under round the year vegetable cultivation for reducing the above mentioned problems. In the context of ever increasing problems of malnutrition and smaller farm size for field crops production, the only feasible option for small households is to grow vegetables intensively in the homestead, which can provide household food security and nutrition for those farmers. Research on homestead vegetable gardening in Palima FSRD site, Tangail was initiated to develop a model for year-round vegetable production in the homesteads to improve the household food security and nutrition of poor farm family through increased intake of home-grown vegetables, to generate additional income for farmers by selling surplus vegetables; and to create employment opportunity for women and children of the family.

\footnotetext{
${ }^{1-5}$ On-Farm Research Division, BARI, Joydebpur, Gazipur1701, Bangladesh.
} 
The participatory farmers under researchers' active supervision from 19992001 at FSRD site, Palima, Tangail, conducted the trial. In designing the vegetable production package, year-round supply of locally adaptable and culturally acceptable vegetable crops having better nutritional value and market potential were taken into consideration. Four small farmers were selected for testing the vegetable patterns. The tested vegetable cropping patterns and their planting and harvesting times are given in Table 1. Some quick growing fruits like papaya were also grown around the gardens. They were trained on important aspects of crop management. The size of the vegetable garden was 2.5 decimal (100 sq.m). This area was divided into five beds, leaving $25 \mathrm{~cm}$ between the beds for irrigation and drainage furrows. Also, $50 \mathrm{~cm}$ space was left around the garden for fencing and drainage. Bamboo made fencing or live fencing and one hand tube-well was ensured to each of the participatory farmers'. Farmers were encouraged to use organic manures from their own sources in the gardens. Inorganic fertilizers for $\mathrm{N}, \mathrm{P}$, and $\mathrm{K}$ were applied in each crop at recommended rates (Handbook of Agril, 1999). Irrigation was applied as and when necessary. Insects were controlled mainly by mechanical means unless there were severe infestations. Data on yield, consumption, distribution and selling of different types of vegetables were collected by using a pre-designed schedule and through continuous monitoring. The nutrient yield per day was calculated by converting the total edible yield into standard units. Means and averages were used for interpretation of the data.

Table 1. Planting and harvesting time of vegetable cropping pattern under each bed at Palirna, Tangail.

\begin{tabular}{|c|c|c|c|c|}
\hline Bed & Vegetable pattern & $\begin{array}{c}\text { Planting/Seeding } \\
\text { time }\end{array}$ & Harvesting time & Variety \\
\hline 1 & $\begin{array}{l}\text { Lady’s finger- } \\
\text { Stem amaranthus- } \\
\text { Red amaranthus- } \\
\text { Brinjal/chilli }\end{array}$ & $\begin{array}{l}\text { 15-25 March } \\
\text { 25-30 July } \\
\text { 10-15 September } \\
\text { 10-15 October }\end{array}$ & $\begin{array}{l}\text { May-July } \\
\text { August-September } \\
\text { October-November } \\
\text { February-March. }\end{array}$ & $\begin{array}{l}\text { BARI Dherosh-I } \\
\text { BARI Danta- I } \\
\text { BARI Lalshak- } 1 \\
\text { BARI Begun-I }\end{array}$ \\
\hline 2. & $\begin{array}{l}\text { Indian spinach - } \\
\text { Red amaranthus- } \\
\text { Radish- } \\
\text { Batisak }\end{array}$ & $\begin{array}{l}\text { 15-20 March } \\
\text { 15-20 August } \\
\text { 20-25 October } \\
\text { 25-30 December }\end{array}$ & $\begin{array}{l}\text { May-August } \\
\text { September-October } \\
\text { December-January } \\
\text { February-March }\end{array}$ & $\begin{array}{l}\text { BARI Puishak-l } \\
\text { BARI Laishak - BARI } \\
\text { Mula- I } \\
\text { BARI Batishak-I }\end{array}$ \\
\hline 3. & $\begin{array}{l}\text { Indian Spinach- } \\
\text { Radish- } \\
\text { Tomato- } \\
\text { Red amaranthus }\end{array}$ & $\begin{array}{l}\text { 15-20 May } \\
\text { 25-30 September } \\
\text { 10-15 November } \\
\text { 12-15 March }\end{array}$ & $\begin{array}{l}\text { May-August } \\
\text { November-December } \\
\text { January- February } \\
\text { April-May }\end{array}$ & $\begin{array}{l}\text { BARI Puishak-l } \\
\text { BARI Mula- } 1 \\
\text { BARI Tomato-2 } \\
\text { BARI Lalshak -1 }\end{array}$ \\
\hline 4. & $\begin{array}{l}\text { Kangkong- } \\
\text { Red amaranthus- } \\
\text { Garden pea- } \\
\text { Red amaranthus- }\end{array}$ & $\begin{array}{l}\text { 15-20 March } \\
\text { 01-05 September } \\
\text { 15-20 October } \\
\text { 20-25 January }\end{array}$ & $\begin{array}{l}\text { May-August } \\
\text { October-November } \\
\text { January-February } \\
\text { March- April - }\end{array}$ & $\begin{array}{l}\text { BARI Gimakalmi-1 } \\
\text { BARI Lalshak } 1 \\
\text { BARI Motorshuti-2 } \\
\text { BARI Laishak -I }\end{array}$ \\
\hline 5. & $\begin{array}{l}\text { Indina spinach } \\
\text { bushbean- } \\
\text { Tomato- } \\
\text { Red amaranthus }\end{array}$ & $\begin{array}{l}\text { 15-20 May } \\
\text { 05-10 September } \\
\text { 20-25 November } \\
\text { 12-15 March }\end{array}$ & $\begin{array}{l}\text { July - August } \\
\text { November- December } \\
\text { January- February } \\
\text { April-May }\end{array}$ & $\begin{array}{l}\text { BARI Puishak-l } \\
\text { BARI bushbean-1 } \\
\text { BARI Tomato-2 } \\
\text { BARI Lalshak-1 }\end{array}$ \\
\hline
\end{tabular}


The harvesting period, edible yield and yield/day of different tested vegetable patterns are presented in Table 2 . The highest edible yield $(111 \mathrm{~kg})$ was obtained from pattern No.-3 which was followed by pattern No.4. Yield variation among the patterns was mainly due to the variation in number and types of vegetable grown. In homegarden of Palima, the highest harvesting period was 220 days with tested pattern 1 though the edible yield was the lowest ( $88 \mathrm{~kg})$. The second highest harvesting period (142 days) was recorded from the tested pattern No.3 which was 78 days shorter than pattern No.1, but edible yield was $26 \%$ higher than pattern No. I. Brinjal and lady's finger of the pattern were harvested for longer duration, while the total yield of radish and tomato of pattern No. 3 of module No.3 yielded more than that of brinjal and lady's finger. Fokhrul et al. (2003) also obtained similar result. The lowest harvesting period (117 days) was recorded from the tested pattern No.5 which pattern produced the second lowest (90 kg) edible yield. As vegetables were grown in sequence, the harvesting period overlapped in different patterns. However, variation exists among the tested modules in supply of year-round vegetables.

Table 2. Harvesting period and yield of different vegetable cropping patterns tested at Palima. Tangail (2.5 dec.).

\begin{tabular}{l|l|l|l}
\hline \multicolumn{1}{c|}{ Patterns } & \multicolumn{1}{c}{$\begin{array}{c}\text { Harvesting period } \\
\text { (days) }\end{array}$} & Edible yield (kg) & Yield/day (kg) \\
\hline 1. & 220 & 88 & 0.40 \\
2. & 130 & 102 & 0.76 \\
3. & 142 & 111 & 0.78 \\
4. & 122 & 108 & 0.89 \\
5. & 117 & 90 & 0.77 \\
\hline Total & - & 499 & 3.60 \\
\hline
\end{tabular}

Table 3. Nutrient contribution from different vegetable patterns tested at Palima, Tangail.

\begin{tabular}{l|l|l|l|l|l}
\hline \multirow{2}{*}{ Pattern No. } & \multicolumn{5}{c}{ Nutrient yield/day } \\
\cline { 2 - 6 } & Protein (g) & $\begin{array}{c}\text { Vitamin A } \\
\text { (I.U) }\end{array}$ & $\begin{array}{c}\text { Vitamin C } \\
(\mathrm{mg})\end{array}$ & calcium (mg) & Iron (mg) \\
\hline 1 & 14.56 & 765 & 31 & 475 & 6.24 \\
2 & 19.18 & 104 & 82 & 470 & 4.41 \\
3 & 21.15 & 409 & 42 & 1574 & 11.06 \\
4 & 34.23 & 900 & 53 & 923 & 20.44 \\
5 & 19.55 & 846 & 43 & 434 & 16.97 \\
Total & 108.67 & 3024 & 251 & 3876 & 59.12 \\
RDA & 149 & 2625 & 140 & 3100 & 49 \\
\hline \% of RDA & 73 & 115 & 179 & 125 & 121 \\
contribution & & & & &
\end{tabular}

RDA = Recommended Dietary Allowance for a family of five (Uddin, K. 1986. and PCARRD, 1988) 
Nutrient contributions from the vegetables grown in different patterns in homegarden of Palima are presented in Table 3. In consideration of Recommended Dietary Allowance (RDA) for a family of five, the vegetable produced in 2.5 decimal area fulfilled the requirement of vitamin 'A', vitamin 'C', calcium, and iron. It also fulfilled $73 \%$ of protein requirement. In considering nutrients, vegetables grown in pattern No. 4 contributed the highest total nutrient yield, while second highest in pattern No. 5 .

Gross return, gross margin of different pattern with variable cost are presented in Table 4. Pattern No.2 was found the most profitable among the patterns tested at Palima, Tangail. Gross margin of that pattern was the highest (Tk. 350) with the lowest variable cost (Tk. 160). The lowest gross margin (Tk. 267) was calculated from the pattern No. 4 with the variable cost (Tk. 179). Total income of 2.5 decimal area was about 3 times higher than production cost (Table 4), therefore, homestead vegetable production was economically viable. In addition, farmers get nutritious food and buildup relationship with neighbours. In the case of production cost assessment, the price of seeds, seedlings, fertilizers and pesticide were considered. Labour cost was not considered as the garden was maintained mostly by the idle family labours.

Table 4. Cost and return $(2.5 \mathrm{dec})$ of different tested vegetable cropping patterns at Palima, Tangail.

\begin{tabular}{l|l|l|l|l}
\hline Pattern No. & \multicolumn{1}{c}{$\begin{array}{c}\text { Gross return } \\
(\mathrm{Tk})\end{array}$} & $\begin{array}{c}\text { Total variable } \\
\text { cost (Tk) }\end{array}$ & $\begin{array}{c}\text { Gross margin } \\
(\mathrm{Tk})\end{array}$ & BCR \\
\hline 1 & 473 & 187 & 286 & 2.53 \\
2 & 510 & 160 & 350 & 3.18 \\
3 & 465 & 164 & 301 & 2.83 \\
4 & 446 & 179 & 267 & 2.49 \\
5 & 460 & 185 & 275 & 2.48 \\
\hline Total & 2354 & 875 & 1729 & 2.70 \\
\hline
\end{tabular}

All of the farmers distributed a portion of their produce to the neighbour and relative to maintain social relationship (Table 5). Farmers consumed about 62, distributed 9 and sold $29 \%$ among the average yearly production of vegetables (499 kg). For a family of five, each small farm produced a good amount of vegetable in all the months except February and March. Maximum vegetable was produced in June to August and November to January (Table 5) as the later two months were driest part of the year and also the time of new plantation of kharif1 vegetable. 
Table 5. Round the year vegetables production and utilization at FSR\&D site, Palima, Tangail (April 1999 to March 2000).

\begin{tabular}{|c|c|c|c|c|}
\hline \multirow[t]{2}{*}{ Name of months } & \multirow[t]{2}{*}{ Total production (kg) } & \multicolumn{3}{|c|}{ Vegetables utilization $(\mathrm{kg})$} \\
\hline & & Intake & Distribution & Sell \\
\hline April 1999 & 33 & 20 & 3 & 10 \\
\hline May1999 & 41 & 25 & 4 & 12 \\
\hline June1999 & 45 & 28 & 4 & 13 \\
\hline July1999 & 55 & 34 & 5 & 16 \\
\hline August 1999 & 42 & 26 & 4 & 12 \\
\hline September1999 & 35 & 22 & 3 & 10 \\
\hline October 1999 & 29 & 18 & 3 & 8 \\
\hline November 1999 & 53 & 33 & 5 & 15 \\
\hline December 1999 & 62 & 38 & 6 & 18 \\
\hline January 2000 & 55 & 34 & 5 & 16 \\
\hline February 2000 & 26 & 16 & 2 & 8 \\
\hline March 2000 & 23 & 14 & 2 & 17 \\
\hline Total & 499 & $308(62)$ & $46(9)$ & $145(29)$ \\
\hline
\end{tabular}

Figure in parenthesis indicate percent utilization of vegetable round the year

Family labours are mostly used in homegarden and homegarden was managed mostly by the idle family labour of male, female, and children (Table 6). Male members participated more in land preparation, planting, mulching, fencing and marketing, etc. while female members participated in applying irrigation, weeding, plant protection, and harvesting. Children members also participated in stalking, weeding, and harvesting.

Table 6. Family labour utilization (\%) in round the year vegetable production at Palima, Tangail (average of $\mathbf{4}$ farmers).

\begin{tabular}{l|l|l|l}
\hline \multicolumn{1}{c|}{ Operations } & Male & Female & Children \\
\hline Land preparation & 74 & 14 & 12 \\
Planting & 47 & 39 & 14 \\
Weeding & 35 & 40 & 25 \\
Mulching & 64 & 20 & 16 \\
Irrigation & 34 & 42 & 24 \\
stalking & 43 & 28 & 29 \\
Fencing & 70 & 19 & 11 \\
Plantprotection & 26 & 51 & 23 \\
Harvesting & 18 & 62 & 20 \\
Marketing & 76 & 05 & 19 \\
\hline Mean & 49 & 32 & 19 \\
\hline
\end{tabular}


The constraints to the adoption of vegetable production by the farmers were non-availability of good quality seed and seedlings. Indigenous knowledge of vegetable seed production, collection and preservation can be improved by future research. In consideration of monetary advantage, homestead vegetable production could not increase farmers' wealth in substantially, but can be efficient means of household food security and nutrition to the small and marginal farmers.

\section{References}

BARC. 1990. Farming Systems Agribusiness Newsletter Vol. 1 No.2. Bangladesh Agricultural Research Council, farmgate, Dhaka.

BBS. 2005. Census of Agriculture-1999. Bangladesh Bureau of Statistics, Statistics Division, Ministry of Planing, Dhaka.

Chadha, M. L., S. Shanmugassundram, A. K. M. A. Hossain and S. M. M. Hossain. 1994. Vegetable research and development in Bangladesh. AVRDC, BARI, Gazipur.

Fakhrul Islam. M., M. Akkas Ali and M. Asraf Ali.2003. Homestead vegetable gardening: A means of homestead food and nutrition security for marginal farmers. Bangladesh J. Agril. Res. 28 (2): 261-270.

Hussain, M. S., M. Z. Abedin, M. A. Quddus and D. Ahmed. 1988. Women's contribution to homestead agriculture production systems in Bangladesh. Bangladesh Academy for Rural Development, Comilla. pp. 344.

PCARRD, 1988. Philippine Council for Agriculture, Forestry and Natural Resources Research and Development. Home gardening program in the Philippines. Los Banos, Laguna, Philippines.

Uddin, K. 1986. Sabji 0 Falayr Pusti. Institute of Nutrition, Dhaka University. 